Тања П. Којић

Универзитет у Новом Саду

Филозофски факултет

Студенткиња докторских студија

tanjakojic2017@gmail.com
УДК: 821.163.41.09-31"19"

821.161.1.09-31

DOI: 10.19090/ZJIK.2021.85-100

оригинални научни рад

\title{
БРАЋА КАРАМАЗОВИ У КОНТЕКСТУ СРПСКОГ РОМАНА 20. ВИЈЕКА $^{1}$
}

САЖЕТАК: Овај рад биће у знаку паралела између руске и српске књижевности. Мистичко-аскетски роман Фјодора Михајловича Достојевског Браћа Карамазови довешћемо у контекст преко јеванђељске архетипологије са српским романима Проклета авлија, Дервиш и смрт и Сеобе. У овом раду видјећемо однос Андрића, Селимовића, Црњанског и Достојевског према хришћанској антропологији и приказати њихове сличне, али и различите интерпретације јеванђељског подтекста и хришћанских истина.

Къучне ријечи: интертекстуалност, контекст, двојништво, јеванђељски архетип, подтекст

\section{1. БРАЋА КАРАМАЗОВИ И ПРОКЛЕТА АВЛИЈА}

Фјодор Михајлович Достојевски својим цјелокупним стваралаштвом оставио је значајан утицај на модерну српску књижевност. У својим дјелима мислио је о човјеку, бавио се проблемом човјека, трагао је за оним што је бесмртно и вјечно у њему. За Достојевског је: „Богочовек смисао и циљ историје; свечовечансто је смисао и циљ човечанства; свечовек је смисао и циљ човека, али не свечовек начињен од отпадака свих религија, већ свечовек=Богочовек“ (Поповић 1923: 1). Човјек је у дјелу Достојевског у средишту: „On je sunce sveta u tom delu, i Dostojevski se muči oko toga da stvori čoveka koji veruje, snažnog, pozitivnog, ali u tome ne uspeva nikada do kraja“ (Berđajev 1981: 22). Достојевски је сматрао да се сви проблеми своде на два, централна односно вјечна проблема: проблем егзистенције Бога и бесмртности душе. Ова два проблема вежу за себе све остале проблеме и

\footnotetext{
1 Рад представља резултат истраживања у оквиру предмета Браћа Карамазови у контексту српског романа 20. века, на докторским студијама на Филозофском факултету у Новом Саду. Ауторка је стипендиста Министарства просвете, науке и технолошког развоја Републике Србије.
} 
воде ка рјешењу које гласи: „Ако има Бога, душа је бесмртна; ако нема Бога, душа је смртна“ (Поповић 1923: 2). У својој књизи Филозофија и религија Ф.М. Достојевског Јустин Поповић пише:

Егзистенција Бога је главно питање, - пише Достојевски Мајкову, којим сам се ја свесно и несвесно мучио целог свог живота. Хероји Достојевског су оваплоћење те главне муке, тог главног питања. Њихова је животна брига, њихово је неизбежно занимање - решавати то главно, то вечно питање; има ли Бога, има ли бесмртности? Без тих питања они су немогући; ван њих - они су несвоји. (Поповић 1923: 23).

Мистичко-аскетски роман Браћа Карамазови посљедњи је роман Фјодора Михајловича Достојевског, који је писао скоро двије године. Роман је објављиван у низу наставака у часопису Руски вјесник све до новембра 1880. године. Књига Браћа Карамазови представља важан роман који истражује хришћанску етику, слободу воље, отуђеност, супарништво, морал. То је духовна драма о моралним дилемама у вези са вјером, о сумњи и модерној Русији: „Mnoštvo samostalnih i neslivenih glasova i svesti, stvarna polifonija punopravnih glasova doista je osnovna odlika romana Dostojevskog“ (Bahtin 2019: 13). У роману писац исказује критички став према времену и друштву, држави и породици, власти и судству, религији, моралу, племству. Достојевски је писао о томе како му се не свиђа лице овога свијета. У свему види разједињеност и недостатак заједништва. У роману су приказана два свијета: свијет племства и свијет обичног народа, сиромаха. У једнима је обијест, неморал зло, а у другима је људско добро и племенитост.

Достојевски је као писац своје стваралаштво посветио православној филозофији и религији. Једно од подручја којима се бавио доминантно је било бављење проблемом човјека и са тим у вези извршио је подјелу својих јунака на: „богоборце и боготражитеље“ (Радуловић 2011: 111). Корпус његових јунака креће се у оквиру демонских и христоликих, што нас одмах доводи и до теме двојништва и једног феномена, а то је феномен подвојене личности:

Од библијских времена она је присутна у светској књижевности и биће у њој присутна све док човек ствара уметност. Зао дух који искушава Христа у пустињи и није ништа друго до његов двојник и посебан израз двојништва као проблема људског постојања (Вулетић 2010: 108). 
Руски писац, уједно и један од највећих свјетских писаца, подстицао је имагинацију Андрића преко свете књиге хришћанства, Библије. Између двојице писаца уочљива је кључна разлика: Достојевски у свом стваралаштву долази до идеје препорода човјечанства и то преко Христове жртве као православни хришћанин, док, за разлику од њега, Андрића религија занима као један од универзалних феномена. У хришћанским идеалима љубави, љепоте, доброте и истине огледа се универзалност феномена. Андрић у дјелу слојевитог значења сабира различите приповједачке гласове који траже свој идентитет и воде ка уланчавању и повезивању различитих људских судбина.

\section{2. ДВОЈНИШТВО КАО ПРОБЛЕМ ПОСТОЈАҢА, ХРИСТОЛИКИ ЈУНАЦИ}

У компаративном стваралаштву тема двојника долази из старозавјетног топоса борбе јеврејског праоца Јакова са Господом и новозавјетног искушавања Христа у пустињи. Старозавјетни архетип о сукобљеној браћи непријатељима Андрић препознаје у историјској причи о Бајазиту и Џем-султану. Код Достојевског можемо препознати један особен тип двојништва, а то је филозофски-психолошко схватање двојника које можемо видјети у разговору Ивана Карамазова са ђаволом. Сјенка насртљиво прогања јунака Достојевског и нагони га да у себи пронађе оно што је непријатељско у свијету који их окружује. Достојевски роман Браћа Карамазови започиње мотом из Јеванђеља по Јовану. Овим избором Достојевски одмах на почетку романа упућује на идеју жртвовања за друге, као и васкрсења. Такво промишљање можемо видјети и у дјелима Иве Андрића кроз идеју жртве за велика дјела, служења човјеку, љубави Божјој. Лик Исуса Христа исијава кроз христолике ликове Аљоше и старца Зосиме. Његове христолике личности одликују врлине попут доброте, смирености, милосрђа и правдољубља.

У роману Проклета авлија можемо видјети архетип страдалника у лику Турчина Ћамила. Подјељеност у лику Савршеног видимо и кроз његово поријекло будући да му је мајка била грчког поријекла, те у вези са тим се додатно појачава подјељена личност Ћамила, која ће кулминирати у проналаску двојника Џем-султана: „Ћамил је човек »мешане крви«, причао је Хаим, од оца Турчина и мајке Гркиње“ (Андрић 2018: 35). Ћамил је био подијељен на хришћанина и муслимана баш као и његов духовни двојник грчко-турског поријекла Џем-султан. У роману долази до бескрајног уланчавања људских судбина преко Ћамиловог поистовјећивања са Христом 
и Џем-султаном, фра Петра са Ћамилом, безименог младића са фра Петром, приповједача и слушаоца. Библијски подтекст романа Проклета авлија води нас ка причи о сукобљеној непријатељској браћи. Мотив двојништва започиње причом о Џем-султану и Бајазиту: „То је у новом и свечаном облику древна прича о два брата. Откако је света и века постоје, и непрестано се поново рађају и обнављају у свету - два брата-супарника“ (Андрић 2018: 52). Старији брат је јачи, мудрији, снажнији, док је млађи све супротно од тога. Сукоб између два брата, Бајазита и Џем-султана, за последицу има раскол у личности млађег брата: „Други је сушта противност његова. Човек кратка века, зле среће и погрешног првог корака, човек чије тежње стално иду мимо оног што треба и изнад оног што се може“ (Андрић 2018: 52). Ћамилово поистовјећивање са Џем-султаном: „Говорило се да је, проучавајући историју турске царевине „преучио“ и, замишљајући да је у њему дух неког несрећног принца, почео да верује да је и сам неки несуђени султан“ (Андрић 2018: 45). Ћамил показује спремност да понесе Џемов крст и прихвати казну намијењену његовом двојнику. На тај начин христолики Ћамил искупљује гријехове несуђеног султана: „Ја сам то! - рекао је још једном тихим али тврдим гласом којим се казују пресудна признања и спустио се на столицу“ (Андрић 2018: 68). Попут Исуса Христа приликом привођења, Һамил је херојски потврдио свој идентитет.

Удвајање, односно подијељеност личности са филозофскопсихолошког схватања видимо у Ивану Карамазову. Иван је до убиства оца сматрао да нема Бога, бесмртности, ђавола. Живио је под троструком догмом атеизма. Али, када Смердјаков у свом животу примјени Иванов императив, код њега долази до драстичне промјене. Иванов тајанствени посјетилац мисли његовим мислима, довршава их, уобличава његово хаотично психичко стање. Тај посјетилац према Ивановом мишљењу је сам ђаво, док је за Достојевског то кошмар-ђаво. Свој први догмат кошмар-ђаво изговара:

Обично се у друштву прима за аксиом да сам ја пали анђео. Бога ми, ја не могу да замислим, како сам ја икада могао бити анђео. Ако сам некада и био, то је било тако давно, да и није грешно заборавити (Достојевски 2019: 511).

У ликовима Аљоше Карамазова и Ћамила можемо видјети хришћанску идеју жртвовања за палог брата. Оно што двојицу ликова додатно спаја јесте генетска повезаност која се огледа у мајкама које су биле нервни болесници. Христолики Аљоша својим животом, својом личношћу, 
говори о томе да Бога има као и бесмртности. Кроз његов израз лица можемо разазнати мир и христолику душу:

Он је био у то време и врло леп, витак, средњег раста, тамносмеђ, са правилним, премда мало дугуљастим овалним лицем, сјајним тамносивим, широко размакнутим очима, веома замишљен и, очигледно, веома спокојан (Достојевски 2019: 17).

Није доказивао да Бог и бесмртност постоје, није вршио притисак, само је показивао. Јустин Поповић у књизи Филозофија и религија Ф.М. Достојевског посебно је писао о христоликим херојима Достојевског: „Христолики хероји Достојевскога чувају највећу драгоценост наше планетеЛик Христов, који у потребним моментима показују поколебаним душама у свету“ (Поповић 1923: 7). Аљоша је био очаран христоликим ликом старца Зосиме, који је њему много помогао да пронађе у себи оно што је христочежњиво и богообразно. О томе много говоре ријечи које је старац Зосима упутио Аљоши:

Благосиљам те на велико послушаније у свету. Нека је Христос с тобом. Сачувај Њега и Он ће тебе сачувати...Тугу видећеш велику и у тузи овој срећан бићеш. Ево теби завет: у тузи среће ишти. Ради, немоуморно ради... Много ћеш противника имати, но и сами непријатељи твоји љубиће те. Много ће ти невоља и несрећа донети живот, но ьима ћеш и срећан бити, и живот благословити, и учинићеш да и други благослове, што је најважније (Достојевски 2019: 330).

Док је отац Пајсије читао Јеванђеље над сандуком у коме је лежао старац Зосима, Аљоша се тихо молио:

И у трећи дан би свадба у Кани Галилејској“ - читаше отац Пајсиј „и ондје бјеше мати Исусова. А позван бјеше и Исус и ученици његови на, свадбу. „-- Свадба? Шта је то... свадба... - летело је као вихор у Аљошиној свести; - ето, и она је срећна... одвезла се на пир... не, није понела нож, није понела нож... то је била само „жална“ реч... а „жалне“ речи треба праштати, неизоставно; жалне речи теше душу... без њих би мука била сувише тешка људима (Достојевски 2019: 288). 
На овом мјесту видјели смо како се тајна људског живота извија у радост, односно како људска душа која је христочежњива завршава свој подвиг небеским браком.

Аљошин однос са Димитријем и Иваном заснива се на привлачењу онога што је у душама његове браће христолико. Он љуби своју браћу, али не и гријехе њихове. Димитрије је говорио: „Брат Иван је сфинга, ћути, само ћути. А мене бог мучи. То ме само и мучи. А шта ћемо ако њега нема?“ (Достојевски 2019: 475). Дио старозавјетне типологије је позив Бога упућен човјеку са намјером службе, коју човјек настоји да избјегне. Димитрије проблем Бога поставља као морални императив. Ако нема Бога, све је дозвољено и његова душа је у двојству између духовног и тјелесног. Однос између браће заснива се на поштовању и уважавању Аљоше од стране Димитрија: „Премда сам рекао да је Иван изнад нас, али ти си ми херувим“ (Достојевски 2019: 477). Мотив удвајања можемо видјети код Ивана Карамазова:

Ниједног тренутка те не примам за реалну истину! - некако бесно викну Иван. - Ти си лаж, ти си болест моја, ти си утвара. Ја само не знам чиме да те уништим, и видим да ћу се неко време морати мучити. Ти си моја халуцинација. Ти си оваплоћење мене самог, уосталом, само једне моје стране... мојих мисли и осећања, и то само најгаднијих и најглупљих. У том погледу ти би за мене могао бити и занимљив, кад бих само имао времена да се с тобом носим (Достојевски 2019: 511).

Ђаво говори у ухо Ивану његове сопствене ријечи, злобно му понавља његове скривене мисли, подругљиво коментарише Иванову одлуку да призна на суду. Разговор који ће након ђавола Иван Карамазов имати са братом Аљошом карактерише: „U ovoj priči Ivan svoje sopstvene misli i odluke ostvaruje odmah u dva glasa, prenosi ih u dve razne tonalnosti“ (Bahtin 2019: 286). Код главних јунака протагониста великог дијалога, као што су Иван и Димитрије Карамазов: „Duboka svest o sopstvenoj nezavršenosti i nerazrešivosti realizuje se već na veoma složenim putevima ideološke misli, zločina i podviga“ (Bahtin 2019: 81).

Поема Велики инквизитор представља критику Христовог плана спасења свијета. У Шпанији током средњег вијека дешава се имагинарни сусрет Христа са инквизитором. Христова намјера била је вјера која би била ослобођена стега, вјера слободног срца, а не вјера изнуђена чудима: 
Филозофска поема Ивана Карамазова је похвала Христовој узвишеној визији људске природе иза које стоји његова жеља да му људи приђу слободно, а не под принудом. Легенда представља похвалу Христовом узвишеном погледу на човека и његове вредносне могућности, али уједно представља и покуду због тога што представа о човеку не одговара стварности (Милошевић 1990: 365).

За Николаја Берђајева легенда је у цјелини једна велика енигма. Аутору није јасно на чијој је страни онај који легенду казује, а на чијој страни је сам аутор легенде: „Himna Hristu se stavlja u usta pobunjenog ateiste „svetlost svetli u tami“ istina o slobodi je neizreciva rečima ljudskog jezika, Hristos je zbog toga sve vreme u senci i neprestano ćuti“ (Berđajev 1981: 32). Овдје видимо поновљену девизу да је у свијету без Христа све дозвољено, што води ка једном виду апокалипсе човјечанства и новом свијету у коме је Антихрист, ђаво нови владар.

Христолики Ћамил обликован је по угледу на христолике јунаке Достојевског, Аљошу и старца Зосиму. Познато је да је Достојевски проучавао живот старца Амвросија и Светог Тихона Заданског и њихови живот су му послужили као модел према којем је обликовао у роману Браћа Карамазови лик старца Зосиме. Достојевски кроз старчев лик наговјештава и извјесну нерепресивну, хуманистичку визију хришћанства. Достојевски је имао утицаја на индивидуализацију Андрићевих ликова који су везани за симболику свјетлости, какав је био Ћамил. Јуродиви ликови из романа Браћа Карамазови као да се преливају у Андрићево дјело. Ћамил је етимолошки одређен као Савршени. У фигури страдалника препознајемо идеју месијанства. Ћамил је био уздржан, у углу, без покрета. Предосјећао је неминовност свог страдања:

Лице младића, меко, подбуло, бело и бледо оним собним бледилом, друкчије од свега што се могло овде очекивати, обрасло у риђу пахуљасту браду од десетак дана и оборене, нешто светлије бркове. Истицали су се велики болеснички и попут убоја тамно колутови, из којих су сјајне од влаге и ватре гледале модре очи (Андрић 2018: 45).

Присјећајући се свог првог сусрета за Ћамилом, фра Петар говори: „Код људи који нам постану блиски ми све те појединости првог додира са њима обично забрављамо; изгледа као да смо их вазда знали и као да су одувек са нама били“ (Андрић 2018: 43). Његове ријечи упућују нас на 
православну идеју подобија, позив човјеку који је створен по лику и подобију Божјем.

\section{3. ПОИМАЬЕ ЉЕПОТЕ, ЉУБАВ-МРЖЬА}

Љепота и доброта су двије категорије које упућују једна на другу и које су истакнуте путем библијских слика. Код Достојевког и Андрића оне упућују на искупитељску љубав. Ријечи које је Димитрије Карамазов упутио Катарини Ивановној:

Она је била лепа у том тренутку што је племенита, а ја подлац; што је она велика због своје великодушности и жртве за оца, а ја стеница. И ето, од мене, стенице и подлаца, она сва зависи, сва, потпуно сва - и душом и телом (Достојевски 2019: 91).

Овдје је жена оваплоћење биједе и потлачености. Мотив згажене љепоте чест је у стваралаштву Достојевског. Његови јунаци су обузети љепотом, као једном врстом чуда. Љепота прогања Димитрија Карамазова као проклетство: „Лепота је страшна и ужасна ствар!“ (Достојевски 2019: 90). Оно што је страшно и застрашујуће у љепоти јесте њена тајновитост. Димитрије Карамазов говорио је и да је љепота тајна која ће спасити свијет. Поред узвишене, у роману Браћа Карамазови имамо и примјере баналне љепоте која представља проституцију. Грушењка је примјер жртве сиромаштва и друштвене потлачености. На тај начин Достојевски показује да љепота и доброта не могу успоставити хармонију у свијету који је несавршен.

Честа тема у дјелима Фјодора Михајловича Достојевског, а која је важна и за овај рад, јесте тема односа љубави и мржње: „Код Достојевског постоји читава галерија ликова носилаца разврата и начела љубави-мржње“ (Вулетић 2010: 114). Љубав-мржња је једна врста пакла у коме је један партнер џелат, а други жртва. Достојевски и Андрић коментаришу Прво Христово чудо, које је у вези са заручницом црквом. Прича о браку, тј. о односу у вези између његових ликова, подсјећа на однос препун антагонизама. Димитрије Карамазов говори Катарини да ју је волио и кад ју је мрзио. Грушењка говори Димитрију да не зна да ли је вољела Пољака или је вољела мржњу према њему коју је у себи гајила. Када је у питању божанска љубав, она је по својој природи таква да какав год гријех човјек починио, она је бесконачна. У прилог овоме говорио је старац Зосима: 
„Важно је покајање јер како се кајеш онако и љубиш“ (Достојевски 2019: 140).

\section{4. БРАЋА КАРАМАЗОВИ И ДЕРВИШ И СМРТ}

О видној повезаности Селимовићевог романа са исламском светом књигом, Кураном, много се говорило. Цитате из Курана које можемо видјети на почетку сваког од шеснаест поглавља романа Дервиш и смрт отварају текст ка хришћанској како религијској тако и филозофској, књижевној и културној традицији. Сурама из Курана Селимовић отвара дјело исламске традиције ка хришћанској, иако је писац сам тумачио курански текст за потребе умјетничког оквира дјела. Структура романа упућује нас на цитатност у дјелу и интертекстуалне релације. У роману се могу препознати алузије и реминисценције које нас упућују на принцип удвајања светих књига Курана и Библије. Меша Селимовић подтекстом се служи ради илуминације неких од древних текстова сада у новом контексту. На роман Достојевског подсјећају бројни филозофски дијалози, као онај између Нурудина и Исхака у затвору, али и разговори са Хасаном. Они приказују релативност онога што се сматра исправним и погрешним у животу, али и у дјелу Дервиш и смрт.

Одмах на почетку романа Селимовић наглашава да Нурудин пише здесна налијево, што је само још једна алузија на Куран, односно на везаност романа са Кураном. Ахмед сасвим јасно зна да је духовни вођа једне текије и да ће за сваки свој поступак одговарати на Судњем дану, али је и свјестан да полако клизи у гријех. Када Ахмех Нурудин дође у дилему да ли да помогне бјегунцу, он је заправо у дилеми да ли да почне прву побуну: „први праисконски грех“ (Реброња 2010: 47). Шеих текије, Ахмед Нурудин, изложен је непрестаном колебању коме се приклонити - џелату или жртви. Они који прогоне су у исто вријеме и потенцијални кривци. Када се први пут приближава бјегунцу, свјестан је да је гријех већ учињен. Нурудин у борби за поробљеног брата доживљава преображај који води до појаве двојника Исхака, отуђеног, издвојеног од свијета који је пун мржње. Јуда и Спаситељ који обитавају у Нурудину доводе га у незавидан положај: „Нисам био ни на једној страни, а мој положај је изузетно важан“ (Селимовић 1969: 39). Ахмед осјећа да више није господар својих поступака. Бјегунац је оличење ђавола који га је придобио за себе. Та два бића, Ахмед и Исхак, дервиш и бјегунац од власти, искушеник и ђаво: „Ахмед верник и Ахмед побуњеник, 
испреплетала су се у Нурудиновом уму тако да их он више не разликује и не спознаје као два засебна бића“ (Реброња 2010: 48).

Проблем дезинтеграције личности, проблем идентитета Ахмеда Нурудина, у вези је са темом двојништва које се јавља и код Достојевског као вид биполарности. Име Нурудиновог двојника Исхака представља алузију на хебрејско-исламску легенду, односно на сина јеврејског праоца Аврама, који је предодређен да зарад вјере буде жртвован и након тога спасен. Мотиви мучења, прогона, разапињања помажу нам да у Исхаку препознамо архетип Христа: „сигурно су гониоци питали за онога што стоји разапет на вратима“ (Селимовић 1969: 39). Специфично је Исхаково лице: „Руке су му још разапете, а лице бљешти као фосфор“ (Селимовић 1969: 40). Симболика бјелине, сјаја, упућује на просвјетљење недужног. Ова алузија се понавља више пута дајући бјегунцу значење жртве, мученика. Након сваког сусрета са фиктивним Исхаком, Нурудин бива богатији за једну нову спознају о себи и свијету око себе:

Čovek se nalazi u ropstvu, on često ne primećuje svoje ropstvo i ponekad ga voli. Ali, čovek isto tako stremi oslobođenju. Pogrešno je misliti da običan čovek voli slobodu. Još je pogrešnije misliti da je sloboda laka stvar. Sloboda je teška stvar. Lakše je ostati u ropstvu (Berđajev 1991: 222).

Нурудин, пали брат, кроз Исхака постепено јача, ослушкује правовјерног. Покушавајући да нечим замијени ослонац без кога је остао, Ахмед у себи гради побуну као нови ослонац. Ахмед је поново научио да воли и осјећа: „Приврженост мртвом брату вратила ми је Хасаново пријатељство“ (Селимовић 1969: 122). Нурудину се враћа љубав према брату Харуну, пријатељу Хасану, заборављеној жени. Ахмед Нурудин се преображава у хришћанског брата. Све док није остао без брата, вјеровао је у бољи и садржајнији свијет због своје посвећености вјери.

Нурудин и Исхак заједно представљају алузију на библијскокуранску легенду о Исаку и Исмаилу. Аврам и његова жена Сара добили су сина Исмаила захваљујући робињи Агари, зато што је Сара била нероткиња. Касније Аврам и Сара добијају сина Исхака. Оба брата су била вође народа, Исмаил Арабљана, а Исхак Јевреја. Као што посланик Ибрахим добија сина и насљедника свог посланства у позним годинама, тако и Ахмед среће Исхака: „у њему се рађа Исхак у годинама у којима се не очекује да се у човеку рађа бунт“ (Реброња 2010: 111). Поред поменуте симболике, значајно 
је уочити и симболику имена Харун, библијског Арона. Харун је име старохебрејског поријекла и значи 'предраги', а то је прави атрибут за брата за кога се Ахмед у цијелом роману бори. Повезницу између Исхака, Арона и Харуна казују ријечи Меше Селимовића: „Претворио се у шибље, израстао у гране, почеће да се њише под вјетром ноћником, што кроз теснац силази низ планине“ (Селимовић 1969: 44). Божји штап у рукама Арона преко ноћи је процвјетао и родио бадеме и на тај начин постао знамење праведника. Исхак у роману Дервиш и смрт Меше Селимовића расте, листа, претвара се у грање налик палици брата Арона: „Исхак се претвара у шибље, у грм, симболишући тиме јављање истине“ (Реброња 2010: 105).

Као што су библијски постојала два брата - Исхак и Исмаил, тако је Ахмед Нурудин био подијељен, располућен на доброг брата Исхака и грешног брата Исмаила. Нурудиново удвајање чини да се он недослиједно опходи према пријатељу Хасану, али и према братовљевој муци и затворености: „У невољи смо и ти и ја, због браће. Ти свога хоћеш да упропастиш, ја свога да спасем“ (Селимовић 1969: 13). Исхак у Нурудиновом животу није само његово друго Ја, него представља и његовог утамниченог и страдалног брата Харуна, кога Ахмед осјећа након његове смрти.

Мотив раскола, односно двојништва можемо видјети у супротним пријатељима Ахмеду и Хасану:

Везао сам се уз њега (добра ријеч: везао, као у олуји, на лађи, на клисури) зато што је рођен да буде друг људима, и што је изабрао баш мене, али ме непрестано и наново одушевљавао што може да буде такав пријатељ управо он, толико пуст и подругљив наизглед. Увијек сам сматрао да је пријатељ човјек који и сам жели ослонац, полутина која тражи допуну, несигуран у себе, помало смољав, нужно досадан, мада драг. А он је цјелац, увијек свјеж и увијек другачији, паметан, смион, немиран, сигуран у свему што је предузимао (Селимовић 1969: 122).

Ахмед Нурудин након свих животних недаћа и неправди у потпуности се мијења. Роман се завршава крајње песимистичким исказом, а писац до краја не изриче јасно да ли је пакао за Ахмеда сама смрт, да ли је то само наговјештај да је Ахмед кажњен, или муке којима се пријети нијекају његове злотворе, или је Ахмед, заправо, спознао Пакао у себи. 


\section{5. БРАЋА КАРАМАЗОВИ И СЕОБЕ}

Вук Исакович, главни лик романа Сеобе Милоша Црњанског, командант Славонско-подунавског пука, предводио је три стотине Срба у аустријско-француском рату. Током 1744. и 1745. године Вук заједно са српским народом тражи избављење и један бескрајан простор мира. У свом походу личио је на хришћанског светитеља, на некога ко је још за живота кренуо путем легенде. Црњански га је представио као човјека противрјечности, који у себи спаја супротне принципе. Код Вука Исаковича можемо видјети паганство и хришћанство, старозавјетно и новозавјетно, демонско и анђеоско. Пратећи његов лик кроз роман Сеобе, уочавамо да је Исакович у сталним колебањима између милосрдног поступања и кажњавања, вјере у оно ка чему тежи, али и сумње у то. Ипак, позитивни принцип је јачи од негативног, те тако Исакович показује и пружа разумијевање, помоћ ка својим војницима и настоји да их одведе пут православља и свега оног што је у њима било изгубљено. У роману Сеобе Црњански преко главне теме активира мит о избављењу српскога народа, гдје читаоци прате пут и повратак српског народа са жељом да очувају своју вјеру и свој крст. Годину дана Вук Исакович провео је у сеоби, тражећи смисао. Већ на почетку романа можемо видјети мотив удвајања, мјесто на коме он себе посматра као туђина:

Мада је хтео, и требао, да пожури, чинио је бесциљне покрете и прекидао облачење дугим посматрањем себе, у огледалу, какво код куће никад видео није. Велики комади његових груди и ногу, његове подбуле очи, жућкасте, пуне тачкица, а нарочито његов трбух, дођоше му у огледалу и смешни и туђи. Навлачећи своје црвене чохе, њему се потпуно учини да се то облачи неко други, а не он, и да ће то неко други сад изићи, накинђурен, из те собе, а не он (Црњански 2019: 19).

Дуго је осјећао да има свог двојника:

Све то прошло је тако бесмислено да се Вуку Исаковичу чинило једнако као да постоје два Вука Исаковича: један који јаше, урла, маше сабљом, гази реке, трчи по гунгули и пуца из пиштоља, идући према Мајнцу, или зидинама Лујевих утврђења, која су се јасно оцртавала над водом, док убијени падају и остају на земљи; и други 
који мирно, као сенка, корача крај њега и гледа и ћути (Црњански 2019: 80).

Мотив огледала у значењу симбола спознаје - јавља се у Посланици Коринћанима апостола Павла посвећеној љубави. Појављивањем мотива огледала добија се утисак да се Вук непрестано колеба између земаљског и небеског царства. Овај мотив открива наличје бића и варљивост свих наших сазнања и искустава. Отвара се питање да ли вјеровати у историјску правичност и смисао живљења? Вук и Аранђел представљају антиподе. Вук је оличење вјере, духовности, идеализма, док је Аранђел окренут ка материјалној сфери.

У роману Сеобе Милоша Црњанског доминантан је сукоб међу браћом због жене. Однос два брата повезан је причом о госпожи Дафини. Супротности између браће јачају у односу према жени. Вуку Исаковичу Дафина је већ одавно досадила:

Њен загрљај, њени безумни напади, њени дуги, неуморни прсти. Њена лепота, крај ватре, надземаљска, њен поглед и њен плач. Огромних груди и огромног трбуха, клонуо, забринут за децу, он се њеном лудилу и крстио и чудио, па и грохотом смејао (Црњански 2019: 5).

За Аранђела Дафина је била попут анђела. Ова прича у роману која чини сижејни ток, сагледана је из више перспектива. Дату ситуацију можемо посматрати са психолошке, филозофске, етичке па и историјске тачке. Љубавни троугао, односно унутрашњи сижејни ток романа може се довести у везу са искуством Проповједника. Исти сукоб међу браћом због жене можемо видјети код Димитрија и Ивана Карамазова. Као Вук и Аранђел, тако Иван и Димитрије представљају антиподе. Уколико их посматрамо, већ од најмлађе доби јасне су разлике:

О старијем, Ивану, саопштићу само то да је растао као неки суморан и сам у себе затворен дечак. Не би се могло рећи да је био бојажљив; али некако као да је још од десет година био прозрео да они расту ипак у туђој породици, и од туђе милости, и да имају таквог оца да је о њему зазорно и говорити, и тако даље. Тај дечак је врло брзо, малтене још као мало дете (бар тако се причало), почео показивати некакве необичне и сјајне способности за учење (Достојевски 2019: $12)$. 
За разлику од Ивана, Димитрије:

Дечаштво и младост његова прођоше неуредно: гимназију није довршио; после ступи у неку војну школу; затим се нађе на Кавказу, доби чин; тукао се у двобоју, био ражалован, поново добио чин, много банчио и потрошио сразмерно много новаца. Почео их је добијати од оца тек као пунолетан, а дотле је направио много дугова (Достојевски 2019: 10).

Госпожа Дафина у расцјепљености између Вука и Аранђела представља жртвовану жену. Она је била затворена у свој свијет, живјећи једним начином живота који је довео до њене трагичности. У својој патњи и сеоби Исакович је видио зрно наде и вјеру у позитиван исход:

Из магловитих испаравања баруштина и блата, из једне неизмерне патње, која се понављала сваки дан, при сеобама, при дављењу стоке, при орању у блатишту и по слатинама, чинило му се да ће одјахати на неки висок брег, у пролетно, топло јутро, где ће добити нешто што ће им свима помоћи, што ће их све развеселити (Црњански 2019: 89).

У свом привиђењу летења Вук подсјећа на Мојсија на Синају. Николај Берђајев у својој књизи Carstvo duha i carstvo ćesara писао је о човјековој слободи и привременом ропству: „Sloboda čoveka je u tome da sem carstva ćesara pronalazi i carstvo Duha u sebi“ (Berđajev 1992: 20). „Негде је морало бити нешто светло, значајно, па треба отићи тамо“ (Црњански 2019: 59). Његова вјера у позитиван принцип однијела је побједу: „Дно дна, међутим, у себи, осећао је да је немогуће да све то тако прође, и како га вуче глас неки, у њему, обећавајући му нешто ванредно, при свршетку“ (Црњански 2019: 62). Глас који је Исакович осјетио је истовјетан Божјем гласу који се јавио Мојсију у књизи Изласка.

\section{6. ЗАКЉУЧАК}

У овом раду настојала сам да прикажем како и на који начин је Достојевски у свом роману врхунског домета Браћа Карамазови подстицао имагинацију Андрића, Селимовића и Црњанског. Сродни традицијски миљеи којима поменути аутори припадају доводе до тога да можемо говорити о узорима и утицајима које је руски писац имао на српске писце. Заједништво аутора можемо видјети и у подтексту којим се служе приликом писања својих дјела, гдје Јеванђеље по Јовану има значајну улогу. Мото из 
Јеванђеља по Јовану као да наткрива све поменуте романе, истичући идеју васкрсења и жртвовања за друге као примарну. У овом раду кроз паралелну анализу настојала сам да покажем и разлике које аутори имају према хришћанској антропологији. Достојевски је као православни хришћанин његовао идеју препорода човјечанства кроз Христову жртву. Андрића је религија занимала као универзални феномен, у коме је посматрао и приступао идеалима истине, доброте, љепоте, љубави. Селимовић је имао нешто другачији приступ канону, те је у њему видио стегу која чини човјека спутаним и због тога врши отклон од њега. Црњански је имао другачији однос према православној традицији - подијељен, будући да је глорификује, али и пародира у контексту патње, страдања и избављења српског народа.

Можемо рећи да оно што је заједничко ауторима чија су дјела предмет овог рада свакако јесте проблем човјека у расколу, који је дио борбе добра и зла, као и архетип сукобљене браће. Проблем жртвовања жена, идеја апостолске мисије одабраних, присутна је кроз идеју васкрсења и жртвовања за друге. Доминантно је и схватање јунака да споразума између различитих, зараћених свјетова, царства Духа и царства Ћесара - нема. Осјећање понижености и увријеђености неминовно је у тренуцима када схвате да им суде, одлучују за њих, третирају их као кривце, недолични људи. Ликови поменутих дијела служе човјеку и човјечности и жртвују се за нека већа дјела и циљеве. Овај рад је примјер да је могуће повући паралелу и аргументовати премису да је Фјодор Михајлович Достојевски романом Браћа Карамазови подстакао имагинацију Андрића, Селимовића и Црњанског.

\section{ИЗВОРИ}

Андрић, Иво. 2018. Проклета авлија. Београд: Sezam Book. Достојевски, М. Фјодор. 2019. Браћа Карамазови I, II. Београд: Лагуна. Селимовић, Меша. 1969. Дервиш и смрт. Београд: Српска књижевна задруга. Црњански, Милош. 2019. Сеобе. Београд: Лагуна.

\section{ЛИТЕРАТУРА}

Вулетић, Витомир. 2010. Руски класици. Нови Сад: Орфеус. Милошевић, Никола. 1990. Достојевски као мислилаи. Београд: Белетра. Поповић, Јустин. 1923. Филозофија и религија Ф.М. Достојевског. Сремски Карловци: Српска манастирска штампарија. 
Реброља, Надија. 2010. Дервиш или човек, живот или смрт. Београд: Службени гласник.

Bahtin, Mihail. 2019. Problemi poetike Dostojevskog. Novi Sad: Akademska knjiga.

Berđajev, Nikolaj. 1981. Duh Dostojevskog. Beograd: Književne novine.

Berđajev, Nikolaj. 1992. Carstvo duha i carstvo ćesara. Novi Sad: Svetovi.

Berđajev, Nikolaj. 1991. O čovekovom ropstvu i slobodi: ogled o personalističkoj filozofiji. Novi Sad: Književna zajednica Novog Sada.

Tanja P. Kojić

\section{THE KARAMAZOV BROTHERS IN THE CONTEXT OF THE SERBIAN NOVEL OF THE 20TH CENTURY}

\section{Summary}

This work will be a sign of parallels between Russian and Serbian literature. We will bring the mystical-ascetic novel by Fyodor Mikhailovich Dostoevsky, The Brothers Karamazov, into context through evangelical archetypology with the Serbian novels The Cursed Courtier, The Dervish and Death and Migration. In this paper, we will observe the relationship of Andrić, Selimović, Crnjanski and Dostoevski towards Christian anthropology and present their similar, but also different interpretations of the Gospel subtext and Christian truths.

Key words: intertextuality, context, duality, evangelical archetype, subtext 